\title{
Solar Cell Parameter Extraction by using the Application of Opposition Based GWO
}

\author{
Ashutosh Sharma, Akash Saxena \\ Department of Electrical Engineering, Swami Keshvanand Institute of Technology, Management and \\ Gramothan, Jaipur-302017 (INDIA) \\ Email-ashusharma199566@gmail.com \\ Received 05.11.2019, accepted 06.10.2020
}

\begin{abstract}
The focus of power producers has shifted from conventional energy sources to sustainable energy sources because of the depletion of fossil fuels and carbon emission causing global warming and climate change. Solar cells are the most prominent option to deal with these problems. The precise estimation of solar cell parameters is very much required before their installation to achieve high efficiency.

In recent years applications of several optimization algorithms for parameter estimation of the solar cell have been addressed. More recently, Opposition Based Grey Wolf Optimizer (OGWO) which is an advanced version of Grey Wolf Optimizer (GWO) has been proposed. The wide applicability of this variant has been examined over some real problems. This fact motivated authors to employ this variant on parameter extraction process. The main motivation behind the implementation of OGWO on solar cell parameter estimation process is the efficiency of this version to deal with complex optimization problems. To estimate the $P V$ cell parameter values, measurement of voltage and current are considered at three important points. Results of OGWO are compared with the results of other variants of GWO on these two models and for three films (Mono crystalline, poly crystalline and thin film). Results reveal that OGWO produces better
\end{abstract}

Keywords -Photovoltaic Module, Parameter Estimation, OGWO Algorithm..

\section{INTRODUCTION}

The conventional energy sources like thermal, hydro, nuclear etc. have their own limitations as lack of availability, creating pollution, producing harmful radiations and complex process of power generation. Hence a powerful and long-lasting energy source is needed which is safe for environment also.Non-conventional energy sources like solar energy, wind power, bio-gas, geothermal, tidal power etc. can provide a solution for this.A separate benefit of renewable energy sources is that, besides being sustainable, such sources offer the benefit of not contributing to greenhouse gas (GHG) emissions, which is an important problem facing in present time. Therefore, such energy sources are often referred to as clean energy forms.Among all renewable energy sources, sun- oriented energy is the most prominent option, due to its infinite availability and no harmful waste as it does not disturb the ecological balance also [1]. To generate the electricity from the solar energy photovoltaic systems are used.

A photovoltaic cell [PV] is a $\mathrm{p}-\mathrm{n}$ junction diode which is typically represented by an analogous electrical circuit $[2,3]$. The PV modules can straightforwardly feed small DC loads but for the larger amount of electricity generation, converter is essential. For efficient utilization, photovoltaic device is required to operate at maximum power point (MPP). In this way, for the comprehensive interpretation, simulation and investigation the manufacturer must know the proper model of a photovoltaic cell. A model can be assumed with one, two and more than two diodes by the designer. Due to the fast convergence rate, simplicity and acceptable accuracy, single diode model has been considered the most popular diode model [4]. However, it shows some limitations when related to the temperature deviations. After that, the double diode model can obtain more accurate results as irradiance gets reduces. Mostly researchers avoid this model due to its complexity because number of unknown parameters are increased as one more diode added. The loss in depletion region is also occurred by the recombination of carriers when one more diode is added [5]. The three-diode model is not so much popular because number of unknown parameters increases exponentially with the increase in number of diodes [6,7,8]. Before the installation of photovoltaic system, the equivalent circuit DC parameters performance prediction depends on an authentic model design. To find the optimum circuit parameters is the main objective of this paper unaffected with the circuit model. For this, transcendental equations are required to relate I-V characteristic of the PV device.

In this paper we are using single diode model and double diode model. Three types of cells are used in single and double diode models i.e. thin-film solar cell, monocrystalline solar cell and polycrystalline solar cell. We are using these films because of their efficiencies. Thin-film cells have efficiency rate of $7-13 \backslash \%$ which can be increased up to $10-16 \backslash \%$. The lifespan and the efficiency of the monocrystalline 
solar cells are $15-201 \%$ where the efficiency of polycrystalline solar cells reaches to $13-161 \%$ [9]. To optimize the value of parameters of PV cells many optimization algorithms have been applied in recent years. Usually an error function should be minimized to provide optimal cell parameters by several optimization algorithms between the set of experimental and simulated I-V data of the PV system. In [10], pattern search optimization approach is applied to extract the single and double diode model parameters. The data used in this paper is actual recorded data and this method shows promising results. In [11], penalty-based differential evolution is used to extract the values of PV cell parameters of two diode model at different atmospheric conditions. An adaptive differential algorithm JADE is improved by using rankingbased mutation and crossover rate repairing technique in [12], known as $\mathrm{R}_{\mathrm{CR}}$-IJADE for the fast and precise extraction. Cuckoo search and bacterial foraging algorithms have been given promising results for minimization of error function in $[13,14]$ respectively.

\section{TYPE OF SOLAR CELL}

There are three main types of solar cell which we use here are as follows:

\subsection{Thin-Film Solar Cell:}

On the basis of technology, $7 \%$ to $13 \%$ efficacy has been achieved by thin film modules. Production modules are works on average $9 \%$ of efficiency [15]. Future module efficiencies are relied upon to climb near the about 10 to $16 \%$.

The advantage of using this movie is that the large-scale production is easy. This makes them and conceivable less expansive to manufacture than crystalline-based solar cells. It is possible to make thin film flexible, which opens up numerous new potential applications. There is very less impact of solar panel performance, high temperature and shading on these types of module. But the issues with these types of modules are that thin film solar panels have low space efficiency that means cost of PV equipment's will increase also the thin film panels degrade faster so that lifespan of this panels is less compared to other two panels.

\subsection{Mono-Crystalline Solar Cell:}

Mono-crystalline solar cells have advantage that they can produce more amount of energy on less available space.Mono-crystalline solar panel efficiency rates are 15 to $20 \%$ and also the lifespan of the mono-crystalline solar cell is longest.Typically, at low light conditions, they perform superior to similarly rated polycrystalline solar panels.But the costliest solar cell is monocrystalline solar cell amongst these solar panels.If the solar panel is partially covered with rain, dust, or ice, the entire circuit of monocrystalline solar panels that break down.Monocrystalline solar panels tend to be more effective in warm weather, but quality is affected as temperature rises.

\subsection{Poly-Crystalline Solar Panels}

The key benefits of polycrystalline solar panels are that the method used to produce polycrystalline silicon is easy and cheaper, also the waste quantity of silicon is also not so much in polycrystalline than in monocrystalline.Polycrystalline solar panels have lower heat sensitivity compared to monocrystalline solar panels, but this impact is minimal, so it does not need to be taken into consideration. But Polycrystalline solar panels have the less efficiency which is approximately $13-16 \%$ i.e. less thanthe monocrystalline solar panels, this is because of the lower silicon purity.

\section{SOLAR CELL MODELLING}

Giving a scientific model that precisely portrays the electrical conduct of sun-oriented cell is very essential. To describe the I-V characteristics of solar cell numerous equivalent circuit models have been developed and proposed. In practice, three commonly used models are Ideal PV cell model, single diode model and double diode model [16].

\subsection{Ideal Diode Model:}

An ideal diode model is shown in Fig1. Theoutput current (I) of the ideal cell is as follows:

$$
I=I_{P V, \text { cell }}+I_{D}
$$

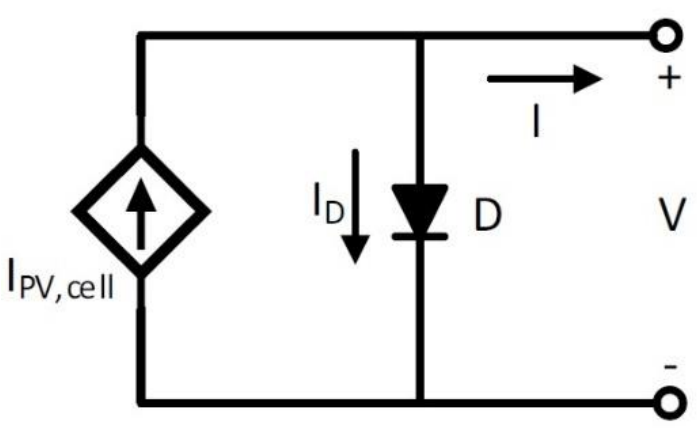

Figure 1:Ideal PV cell circuit model

Where, diode current is $I_{D}$ and it can be expressed as Shockley diode equation. $\mathrm{I}_{\mathrm{PV} \text {,cell }}$ is the photovoltaic current which is generate due to incident light. Now Eq. (1) can be written as:

$$
I=I_{P V, \text { cell }}-I_{O, \text { cell }}\left[\exp \left(\frac{q V}{n k T}\right)-1\right]
$$


The diode current is function of $\mathrm{I}_{\mathrm{O} \text {,cell }}$ (reverse saturation current), an electro charge (q), Boltzmann constant $(\mathrm{K})$, absolute temperature of diode junction's ( $\mathrm{T}$ in Kelvin) and ideality factor (n).

To configure a module a few PV cells are associated either in series or in parallel as a general rule. $\mathrm{N}_{\mathrm{C}}$ is considered as number of cells which are connected in series because more prominent output voltage is given by series connection. In this manner, the more feasible comparable circuit models of PV modules are examined.

\subsection{Single Diode Model:}

This model is considered due to its simplicity and better accuracy point of view. As shown in Figure 2, single diode model comprises of five parameters, namely current source, single diode, one ideality factor and two resistors.

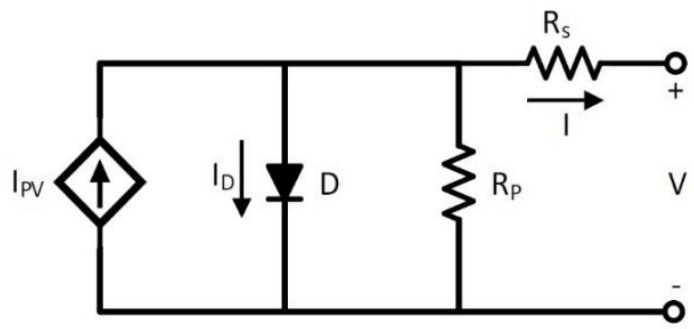

Figure 2: PV module of single diode equivalent circuit model

The I-V characteristic is shown as:

$I=I_{P V}-I_{O}\left[\exp \left(\frac{q\left(V+I R_{S}\right)}{n k N_{C} T}\right)-1\right]-\left(\frac{V+I R_{S}}{R_{P}}\right)$

By Eq (3), at open circuit point $\mathrm{I}=0$ and $\mathrm{V}=\mathrm{V}_{\mathrm{OC}}$ :

$I_{P V}=I_{O}\left[\exp \left(\frac{q V_{O C}}{n k N_{C} T}\right)-1\right]+\frac{V_{O C}}{R_{P}}$

At short circuit point $\mathrm{V}=0$ and $\mathrm{I}=\mathrm{I}_{\mathrm{SC}}$, then from Eq. (3):

$I_{P V}=I_{S C}+I_{O}\left[\exp \left(\frac{q R_{S} I_{S c}}{n k N_{C} T}\right)-1\right]+\frac{R_{S} I_{S C}}{R_{P}}$

From equation (4) and (5) we find:

$I_{O}=\frac{I_{S C}+\frac{R_{S} I S C}{R_{P}}-\frac{V_{O C}}{R_{P}}}{\exp \left(\frac{q V_{O C}}{n k N_{C} T}\right)-\exp \left(\frac{q R_{S} I_{S C}}{n k N_{C} T}\right)}$

Substitute Eq. (6) in Eq. (4), we get:

$$
I_{O}=\frac{\left(I_{S C}+\frac{R_{S} I_{S C}}{R_{P}}-\frac{V_{O C}}{R_{P}}\right)\left[\exp \left(\frac{q V_{O C}}{n k N_{C} T}\right)-1\right]}{\exp \left(\frac{q V_{O C}}{n k N_{C} T}\right)-\exp \left(\frac{q R_{S} I_{S C}}{n k N_{C} T}\right)}+\frac{V_{O C}}{R_{P}}
$$

\subsection{Double Diode Model:}

Another approach to depict solar cell electrical conduct, is to model it by adding another diode parallel to a modifying diode. Furthermore, a resistor represents the solar cell metal contacts and semiconductor material mass opposition associated in arrangement with the cell shunt components [17].Figure 3 shows the double diode circuit model, mathematical representation of this diode modelis derived as:

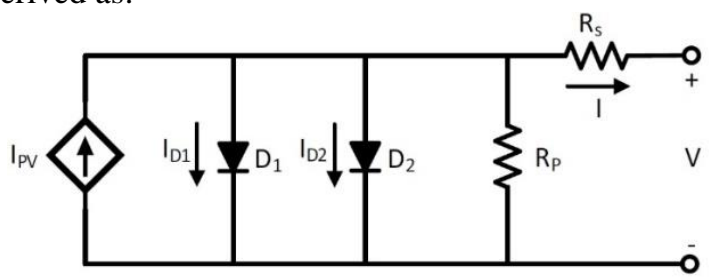

Figure 3: PV module of double diode equivalent model. $\mathrm{I}-\mathrm{V}$ characteristics of this model is presented as $I=I_{P V}-I_{D_{1}}-I_{D_{2}}-\frac{V+I R_{S}}{R_{P}}$

\section{OBJECTIVE FUNCTION}

In this research work, three different types of photovoltaic cell modules have been contemplated which are thin film, polycrystalline solar cell and monocrystalline solar cell. Mostly by the manufacturer very less information is available. At standard test conditions the data of current and voltage is given by the manufacturer is $25^{\circ}$ temp. and irradiance is $1000 \mathrm{~W} / \mathrm{m}^{2}$, at three very important points (short circuit point, open circuit point and maximum power point).

The problem of estimation is converted into the optimization with an objective to precisely extract photovoltaic cell parameters. In most of the cases, maximum power point measurements were considered but in this work all three major points are considered for objective function formulations. In Table 1 the details of optimized parameters and calculated parameters are shown. The objective function can be given as per equation (9).

Table 1: Calculated parameters and Extracted variables for both diode model of solar cells.

\begin{tabular}{|c|c|c|}
\hline Model & $\begin{array}{c}\text { Extracted } \\
\text { Parameters }\end{array}$ & $\begin{array}{c}\text { Calculated } \\
\text { Parameters }\end{array}$ \\
\hline SDM & $\mathrm{n}, \mathrm{R}_{\mathrm{S}}, \mathrm{R}_{\mathrm{P}}$ & $\mathrm{I}_{\mathrm{S}}, \mathrm{I}_{\mathrm{PV}}$ \\
\hline $\mathrm{DDM}$ & $\mathrm{n}_{1}, \mathrm{n}_{2}, \mathrm{R}_{\mathrm{S}}, \mathrm{R}_{\mathrm{P}, \mathrm{I}_{\mathrm{O} 1}}$ & $\mathrm{I}_{\mathrm{O} 2}, \mathrm{I}_{\mathrm{PV}}$ \\
\hline
\end{tabular}

Now sum of square errors is taken as the main aim of optimization method. So that, the aggregate error has to be minimized as:

$$
E R R=e r r_{O C}^{2}+e r r_{S C}^{2}+e r r_{M P P}^{2}
$$

$\mathrm{Eq}$ (9) shows the desired objective function to achieve the finest accuracy in the estimation process

\section{GREY WOLF OPTIMIZER (GWO)}

GWO is a contemporary population-based swarm intelligence approach. This method was proposed by Mirjalili et.al [18], that is inspired by the grey wolf behavior. In nature, grey wolves have the qualities of hunting mechanism and leadership hierarchy and GWO imitates these advantages. GWO is a mathematical mimicry of the hunting 
behavior of predator wolves. Grey wolves are related from the Canidae family. Grey wolves prefer to live in a group of 5-12 wolf members on average. The wolves are separated in four categories: Alpha wolves are the dominant wolves in all four categories and is also the decision makers. After alpha wolves, beta wolves came at second position as per their dominance. Beta wolves are used to assist alpha wolves in decisionmaking or in other group activities. Delta wolves follow the orders of the alpha and beta wolves. In the hierarchy, omega wolves come at the last position and the role of scapegoat is played by these wolves.According to $[15,16]$, the major hunting stages tracks, pursues, surrounds and attacks the prey.

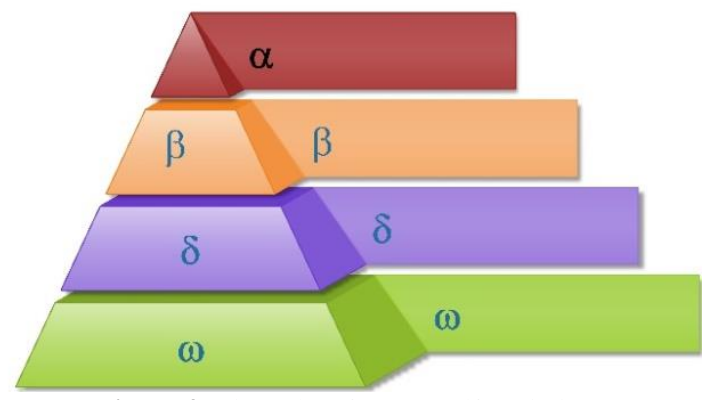

Figure 4: Hierarchy of Grey Wolf Optimizer

The important procedure is elaborated in the algorithm are as follows:

\subsection{Encircling Prey:}

The grey wolves encircled the prey which is represented as follows:

$$
\begin{aligned}
& \vec{S}=\left|\vec{R} \cdot \vec{X}_{p}(i)-\vec{X}(i)\right| \\
& \vec{X}(i+1)=\vec{X}_{p}(i)-\vec{P} \cdot \vec{S}
\end{aligned}
$$

Where current iteration is represented by $\mathrm{i}$, grey wolf position vector is $\vec{X}, \vec{P}$ and $\vec{R}$ are the coefficient vectors, the prey's position vector is $\vec{X}_{p}$. Vectors $\vec{P}$ and $\vec{R}$ can be calculated as follows:

$$
\vec{P}=2 \vec{C} \cdot \vec{r}_{1}-\vec{C}
$$

$\vec{R}=2 \cdot \vec{r}_{2}$

where $r_{1}$ and $r_{2}$ are the random numbers and control vector $\vec{c}$ decreases linearly from 2 to 0 .

\subsection{Hunting the Prey:}

In the search space, it is not possible to find proper location of prey. Hence, to require the social hierarchy three best solutions $(\alpha, \beta$ and $\delta)$ are kept. This fact can be visualized by following mathematical representation:

$$
\begin{aligned}
& \vec{S}_{\alpha}=\left|\vec{R}_{1} \vec{X}_{\alpha}-\vec{X}\right|, \vec{S}_{\beta}=\left|\vec{R}_{2} \vec{X}_{\beta}-\vec{X}\right|, \vec{S}_{\delta}= \\
& \left|\vec{R}_{3} \vec{X}_{\delta}-\vec{X}\right|
\end{aligned}
$$

$$
\begin{aligned}
\vec{X}_{x}= & \vec{X}_{\alpha}-\vec{A}_{x} \cdot\left(\vec{D}_{\alpha}\right), \\
\vec{X}_{z}= & \vec{X}_{\delta}-\vec{A}_{z} \cdot\left(\vec{D}_{\delta}\right) \\
& \vec{X}_{(i+1)}=\frac{\vec{X}_{x}+\vec{X}_{y}+\vec{X}_{z}}{3}
\end{aligned}
$$

The position updation represented by the equations according to alpha where the distance of the prey are $\vec{S}_{\alpha}, \vec{S}_{\beta}$ and $\vec{S}_{\delta}$ from $\alpha, \beta$ and $\delta$ respectively.

\subsection{Attacking the Prey:}

This stage is accountable for exploitation and can be controlled by linear decrement in $\vec{c}$. Grey wolves are empowered by using linear decrement in $\vec{c}$ to assult the prey, while it stops moving. By changing $\vec{c}$, variation in $\vec{P}$ can be controlled i.e. there are more fluctuations in $\vec{P}$ if the value of $\vec{c}$ is higher.

\section{OPPOSITIONAL-BASED GREY WOLF OPTIMIZATION (OGWO)}

In optimization methods search starts from some initial guess or from a random point. If the initial point is near to the optimal solution, then convergence can be achieved faster. On the other hand, if the chosen initial point is far away from the optimal location the convergence takes more time. To reach the solution at minimum time shows the efficiency of all the algorithms.

As per the following mathematical presentation opposite number can be defined as:

Let a real number be $\mathrm{x} \in[\mathrm{lb}, \mathrm{ub}]$. Then $\mathrm{y}^{*}$ opposite number can be written as:

$$
x^{*}=l b+u b-x
$$

Eq. (6.1) is defined for only one-dimensional search space. Similarly, for $\mathrm{n}$ different dimensional search space opposite number can be described as:

Let $\mathrm{X}=\left(\mathrm{x}_{1}, \mathrm{x}_{2}, \ldots ., \mathrm{x}_{\mathrm{N}}\right) \in \mathrm{R}$ and $\mathrm{x}_{\mathrm{i}} \in\left[\mathrm{lb}_{\mathrm{i}}, \mathrm{ub} \mathrm{b}_{\mathrm{i}}\right] \in\{1$, $2, \ldots, \mathrm{N}\}$. Now the opposite number $\mathrm{X}^{*}=\left(x_{1}^{*}, x_{2}^{*}\right.$, $\left.\ldots, x_{N}^{*}\right)$ can be defined as:

$x_{i}^{*}=l b_{i}+u b_{i}-x_{i}$

\section{RESULTS}

\subsection{Results for Single-Diode Model}

This section, summarizes and analyzes the simulation results for various solar cells using the application of OGWO [19] algorithm.For fair comparison, values of maximum iteration and search agents are kept same for all optimization algorithms. From table 2, we can observe that the mean value of error is reaching to $10^{-12}$ for thin-film and the standard deviation is also optimal. Low values of standard deviation are indicator of better solution quality. In Fig 5, we can see the convergence curve of both single diode model and double diode model. Form this figure one can easily 
conclude that OGWO exhibits superior convergence properties. Table 3 shows the extracted parameters value for single diode model.

The same optimization study is carried out for polycrystalline and monocrystalline solar cells. In case of monocrystalline solar panel mean value of error is not best but it is approximately near to the competitors. Hence, it can be concluded that OGWO works satisfactorily.

\subsection{Results for Double-Diode Model}

Double diode models are employed to obtain better accuracy. Five circuit parameters are extracted by using OGWO, while the rest of two parameters are determined by the mathematical relation they share with the extracted parameters.
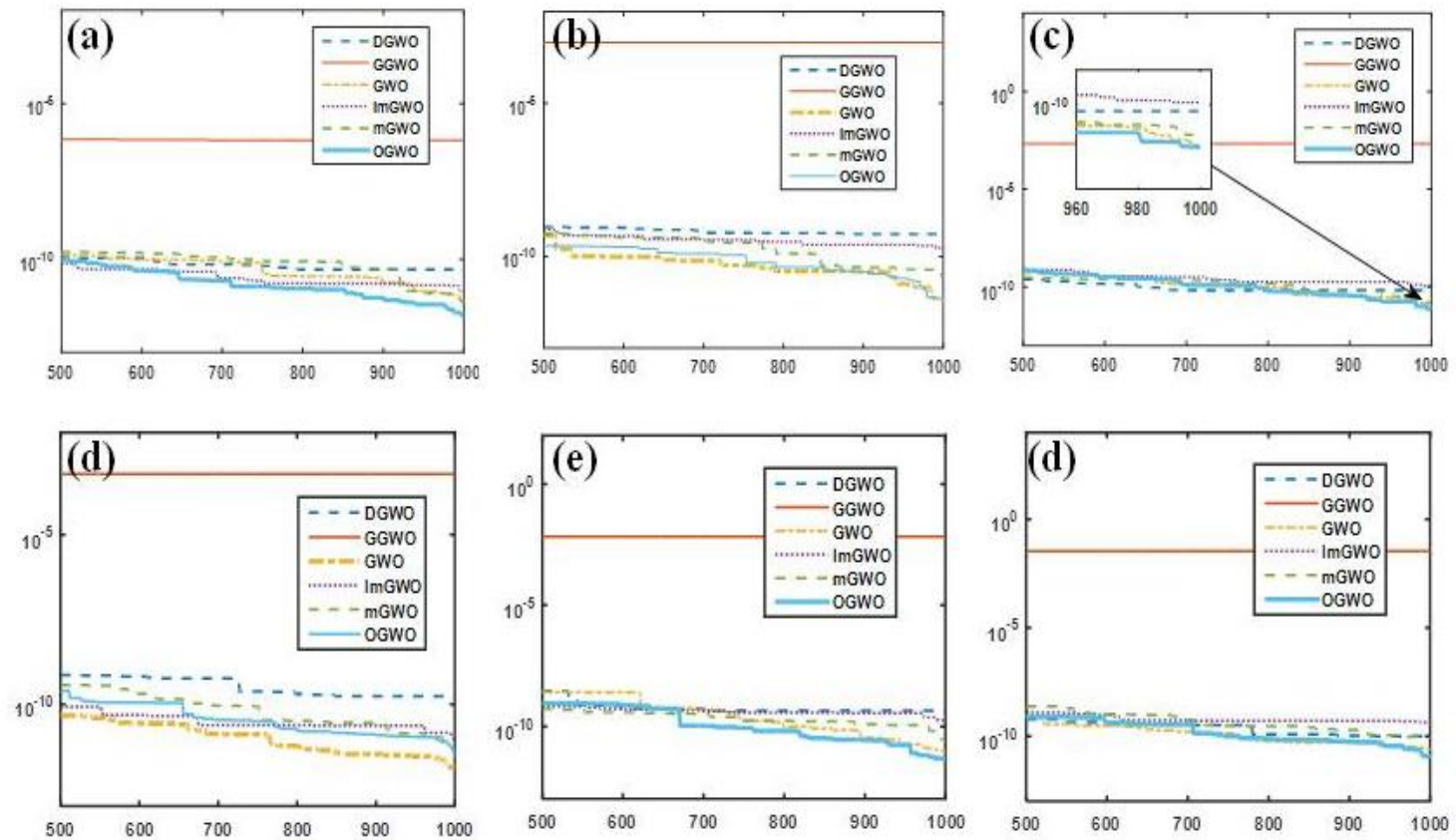

Figure 5: Convergence Curve of Single Diode Model: (a) Thin-Film (b) Monocrystalline cell (c) Polycrystalline celland Double Diode Model: (d) Thin-Film (e) Monocrystalline cell (f) Polycrystalline cell

\section{CONCLUSION}

This paper has presented an application of recently published GWO variant (OGWO) for parameter estimation problem of solar cells through two well-known circuit models.Extraction of parameters has been done by using the data sheet information at three important points of $\mathrm{I}-\mathrm{V}$ characteristics. The detailed analyses of single and double diode models are presented. The implementation of OGWO algorithm has been described in detail and obtained results have been compared with other variants of GWO.
From table 2 it can be observed that the standard deviation value is low for all three films of both models but the mean value of error is less in monocrystalline and polycrystalline solar panels but for thin-film the mean value is not best but falls in a very narrow range with other competitors. Table 4 shows the extracted parameters values for double iode model. Fig 5 shows the convergence curves of both models. From this analysis, we can conclude that OGWO shows satisfactory optimization properties. The same conclusion can be obtained from presented analysis 
Table 2: Comparative Error Analysis of OGWO and other GWO Variants of Single Diode Model and Double Diode Model

\begin{tabular}{|c|c|c|c|c|c|c|c|c|}
\hline$\frac{\bar{d}}{8}$ & 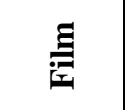 & & $\begin{array}{c}\text { MGWO } \\
{[20]}\end{array}$ & $\begin{array}{c}\text { GGWO } \\
{[22]}\end{array}$ & $\begin{array}{c}\text { GWO } \\
{[18]}\end{array}$ & $\begin{array}{c}\text { ImGWO } \\
{[23]}\end{array}$ & $\begin{array}{c}\text { mGWO } \\
{[21]}\end{array}$ & OGWO \\
\hline \multirow{12}{*}{ 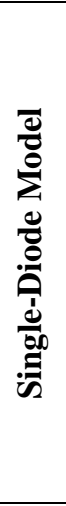 } & \multirow{4}{*}{ 首具 } & $\min$ & $1.114 \mathrm{E}-13$ & $3.817 \mathrm{E}-12$ & $1.948 \mathrm{E}-18$ & $7.846 \mathrm{E}-15$ & $4.899 \mathrm{E}-17$ & $8.714 \mathrm{E}-15$ \\
\hline & & $\max$ & $2.892 \mathrm{E}-10$ & $1.929 \mathrm{E}-05$ & $1.028 \mathrm{E}-10$ & $5.004 \mathrm{E}-11$ & $3.620 \mathrm{E}-11$ & $1.229 \mathrm{E}-11$ \\
\hline & & SD & $7.297 \mathrm{E}-11$ & 3.519E-06 & $1.873 \mathrm{E}-11$ & $1.609 \mathrm{E}-11$ & $7.185 \mathrm{E}-12$ & $2.678 \mathrm{E}-12$ \\
\hline & & mean & $4.713 \mathrm{E}-11$ & $6.583 \mathrm{E}-07$ & $4.449 \mathrm{E}-12$ & $9.149 \mathrm{E}-12$ & $4.511 \mathrm{E}-12$ & $1.577 \mathrm{E}-12$ \\
\hline & \multirow{4}{*}{ 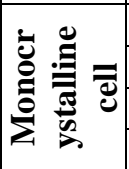 } & $\min$ & $5.387 \mathrm{E}-14$ & $5.010 \mathrm{E}-11$ & $2.146 \mathrm{E}-17$ & $1.280 \mathrm{E}-14$ & $2.064 \mathrm{E}-17$ & $9.655 \mathrm{E}-17$ \\
\hline & & $\max$ & $6.437 \mathrm{E}-09$ & $8.500 \mathrm{E}-03$ & $5.196 \mathrm{E}-11$ & $7.551 \mathrm{E}-10$ & $1.991 \mathrm{E}-10$ & $5.503 \mathrm{E}-11$ \\
\hline & & SD & $1.316 \mathrm{E}-09$ & $2.100 \mathrm{E}-03$ & $1.014 \mathrm{E}-11$ & $2.329 \mathrm{E}-10$ & $4.482 \mathrm{E}-11$ & $1.078 \mathrm{E}-11$ \\
\hline & & mean & $5.326 \mathrm{E}-10$ & $9.751 \mathrm{E}-04$ & $3.699 \mathrm{E}-12$ & $1.681 \mathrm{E}-10$ & $2.099 \mathrm{E}-11$ & $4.006 \mathrm{E}-12$ \\
\hline & \multirow{4}{*}{ 总 } & $\min$ & $6.238 \mathrm{E}-14$ & $1.694 \mathrm{E}-10$ & $2.025 \mathrm{E}-14$ & $5.918 \mathrm{E}-14$ & $2.712 \mathrm{E}-15$ & $7.482 \mathrm{E}-17$ \\
\hline & & $\max$ & $3.393 \mathrm{E}-10$ & $1.190 \mathrm{E}-02$ & $6.095 \mathrm{E}-11$ & $6.746 \mathrm{E}-10$ & $1.163 \mathrm{E}-10$ & $4.828 \mathrm{E}-11$ \\
\hline & & SD & $8.467 \mathrm{E}-11$ & $2.900 \mathrm{E}-03$ & $1.459 \mathrm{E}-11$ & $1.677 \mathrm{E}-10$ & $2.338 \mathrm{E}-11$ & $1.283 E-11$ \\
\hline & & mean & $6.761 \mathrm{E}-11$ & $2.100 \mathrm{E}-03$ & $8.284 \mathrm{E}-12$ & $1.150 \mathrm{E}-10$ & $1.527 \mathrm{E}-11$ & $7.070 \mathrm{E}-12$ \\
\hline \multirow{12}{*}{ 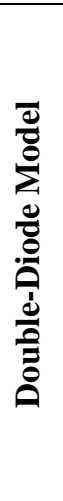 } & \multirow{4}{*}{ 总 } & $\min$ & $1.673 \mathrm{E}-15$ & $1.242 \mathrm{E}-13$ & $4.349 \mathrm{E}-16$ & $2.416 \mathrm{E}-14$ & $1.015 \mathrm{E}-16$ & $3.196 \mathrm{E}-15$ \\
\hline & & $\max$ & $1.015 \mathrm{E}-09$ & $4.500 \mathrm{E}-03$ & $1.458 \mathrm{E}-11$ & $7.558 \mathrm{E}-11$ & $3.764 \mathrm{E}-11$ & $4.527 \mathrm{E}-11$ \\
\hline & & SD & $3.012 \mathrm{E}-10$ & $1.000 \mathrm{E}+01$ & $2.863 \mathrm{E}-12$ & $1.590 \mathrm{E}-11$ & $7.294 \mathrm{E}-12$ & $8.450 \mathrm{E}-12$ \\
\hline & & mean & $1.715 \mathrm{E}-10$ & $6.087 \mathrm{E}-04$ & $1.347 \mathrm{E}-12$ & $9.510 \mathrm{E}-12$ & 3.947E-12 & $2.913 \mathrm{E}-12$ \\
\hline & \multirow{4}{*}{ 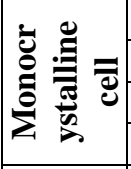 } & $\min$ & $3.803 \mathrm{E}-15$ & $2.082 \mathrm{E}-11$ & $3.589 \mathrm{E}-15$ & $1.473 \mathrm{E}-13$ & $9.093 \mathrm{E}-15$ & $2.326 \mathrm{E}-17$ \\
\hline & & $\max$ & $6.061 \mathrm{E}-09$ & $4.530 \mathrm{E}-02$ & $7.237 \mathrm{E}-11$ & $1.856 \mathrm{E}-09$ & $1.380 \mathrm{E}-10$ & $7.867 \mathrm{E}-11$ \\
\hline & & SD & $1.147 \mathrm{E}-09$ & $1.050 \mathrm{E}-02$ & $1.777 \mathrm{E}-11$ & $3.503 \mathrm{E}-10$ & $3.578 \mathrm{E}-11$ & 1.439E-11 \\
\hline & & mean & $4.485 \mathrm{E}-10$ & $6.800 \mathrm{E}-03$ & $8.141 \mathrm{E}-12$ & $1.651 \mathrm{E}-10$ & $2.508 \mathrm{E}-11$ & $4.297 \mathrm{E}-12$ \\
\hline & \multirow{4}{*}{ 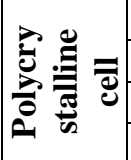 } & $\min$ & $1.922 \mathrm{E}-15$ & $2.070 \mathrm{E}-07$ & $5.118 \mathrm{E}-16$ & $1.099 \mathrm{E}-14$ & $1.030 \mathrm{E}-15$ & $2.127 \mathrm{E}-15$ \\
\hline & & $\max$ & $1.194 \mathrm{E}-09$ & $4.623 \mathrm{E}-01$ & $2.651 \mathrm{E}-10$ & $1.437 \mathrm{E}-09$ & $9.078 \mathrm{E}-10$ & $1.191 \mathrm{E}-10$ \\
\hline & & SD & $2.368 \mathrm{E}-10$ & $9.210 \mathrm{E}-02$ & $5.639 \mathrm{E}-11$ & $4.503 \mathrm{E}-10$ & $1.931 \mathrm{E}-10$ & $2.686 \mathrm{E}-11$ \\
\hline & & mean & $1.009 \mathrm{E}-10$ & $3.350 \mathrm{E}-02$ & $2.305 \mathrm{E}-11$ & $3.160 \mathrm{E}-10$ & $8.599 \mathrm{E}-11$ & 1.051E-11 \\
\hline
\end{tabular}

Table 3:Table Extracted Parameters values for Single Diode Model

\begin{tabular}{|c|c|c|c|c|c|c|c|}
\hline$\frac{\stackrel{0}{E}}{\stackrel{0}{E}}$ & Parameters & $\begin{array}{c}\text { MGWO } \\
{[20]}\end{array}$ & GGWO [22] & GWO [18] & $\underset{[23]}{\operatorname{ImGWO}}$ & $\begin{array}{c}\text { mGWO } \\
{[21]}\end{array}$ & OGWO \\
\hline \multirow{5}{*}{ 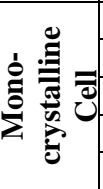 } & $\mathrm{n}$ & 1.5700 & 1.3800 & 1.7500 & 1.4300 & 1.7100 & 1.8300 \\
\hline & $\mathrm{R}_{\mathrm{S}}$ & 0.0782 & 0.2860 & 0.1230 & 0.2620 & 0.1190 & 0.0904 \\
\hline & $\mathrm{R}_{\mathrm{P}}$ & 67.7000 & 117.0000 & 138.0000 & 110.0000 & 120.0000 & 141.0000 \\
\hline & $\mathrm{I}_{\mathrm{S}}$ & $6.83 \mathrm{E}-06$ & $2.04 \mathrm{E}-06$ & $1.93 \mathrm{E}-05$ & $4.00 \mathrm{E}-06$ & $1.83 \mathrm{E}-05$ & $2.56 \mathrm{E}-05$ \\
\hline & $\mathrm{I}_{\mathrm{PV}}$ & 5.4600 & 5.4600 & 5.4600 & 5.4600 & 5.4600 & 5.4600 \\
\hline \multirow{5}{*}{ 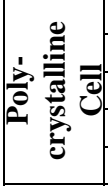 } & $\mathrm{n}$ & 0.9910 & 1.0100 & 1.1000 & 1.0800 & 1.1200 & 1.0300 \\
\hline & $\mathrm{R}_{\mathrm{S}}$ & 0.0546 & 0.2470 & 0.1060 & 0.1940 & 0.0626 & 0.0976 \\
\hline & $\mathrm{R}_{\mathrm{P}}$ & 55.0000 & 107.0000 & 73.3000 & 96.7000 & 66.7000 & 59.5000 \\
\hline & $\mathrm{I}_{\mathrm{S}}$ & $1.79 \mathrm{E}-07$ & $3.76 \mathrm{E}-07$ & 3.69E-07 & $1.77 \mathrm{E}-07$ & $2.75 \mathrm{E}-07$ & 6.37E-08 \\
\hline & $\mathrm{I}_{\mathrm{PV}}$ & 8.2200 & 8.2300 & 8.2200 & 8.2300 & 8.2200 & 8.2200 \\
\hline \multirow{5}{*}{ 畐 } & $\mathrm{n}$ & 0.7720 & 1.3200 & 1.5500 & 1.5900 & 1.5800 & 1.6000 \\
\hline & $\mathrm{R}_{\mathrm{S}}$ & 0.0727 & 0.4280 & 0.4630 & 0.5740 & 0.4550 & 0.5240 \\
\hline & $\mathrm{R}_{\mathrm{P}}$ & 63.7000 & 77.8000 & 97.4000 & 104.0000 & 102.0000 & 105.0000 \\
\hline & $\mathrm{I}_{\mathrm{S}}$ & $5.64 \mathrm{E}-07$ & 9.14E-07 & $3.63 \mathrm{E}-06$ & $3.83 \mathrm{E}-06$ & $3.99 \mathrm{E}-06$ & $3.94 \mathrm{E}-06$ \\
\hline & $\mathrm{I}_{\mathrm{PV}}$ & $2.68 \mathrm{E}+00$ & $2.69 \mathrm{E}+00$ & $2.69 \mathrm{E}+00$ & $2.70 \mathrm{E}+00$ & $2.69 \mathrm{E}+00$ & $2.69 \mathrm{E}+00$ \\
\hline
\end{tabular}


Table 4: Extracted Parameters values for Double Diode Model

\begin{tabular}{|c|c|c|c|c|c|c|c|}
\hline Module & Parameters & $\begin{array}{c}\text { MGWO } \\
{[20]}\end{array}$ & $\begin{array}{c}\text { GGWO } \\
{[22]}\end{array}$ & GWO [18] & $\begin{array}{c}\operatorname{ImGWO} \\
{[23]}\end{array}$ & $\begin{array}{c}\text { mGWO } \\
{[21]}\end{array}$ & OGWO \\
\hline \multirow{7}{*}{ 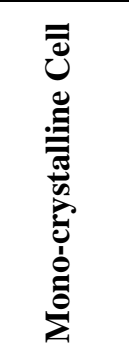 } & $\mathrm{n}_{1}$ & 1.5200 & 1.7600 & 1.7400 & 1.8000 & 1.8800 & 1.8200 \\
\hline & $\mathrm{n}_{2}$ & 1.4700 & 1.2900 & 1.5600 & 1.4100 & 1.6400 & 1.7000 \\
\hline & $\mathrm{R}_{\mathrm{S}}$ & 0.0914 & 0.3150 & 0.1660 & 0.2540 & 0.1310 & 0.0997 \\
\hline & $\mathrm{R}_{\mathrm{P}}$ & 57.0000 & 130.0000 & 105.0000 & 107.0000 & 108.0000 & 117.0000 \\
\hline & $\mathrm{I}_{\mathrm{O} 1}$ & $8.59 \mathrm{E}-08$ & $5.42 \mathrm{E}-07$ & $3.11 \mathrm{E}-07$ & $4.35 \mathrm{E}-07$ & $3.84 \mathrm{E}-07$ & 4.47E-07 \\
\hline & $\mathrm{I}_{\mathrm{O} 2}$ & $3.12 \mathrm{E}-06$ & 2.97E-06 & $1.25 \mathrm{E}-05$ & $2.86 \mathrm{E}-06$ & $1.56 \mathrm{E}-05$ & $1.72 \mathrm{E}-05$ \\
\hline & $\mathrm{I}_{\mathrm{PV}}$ & 5.4600 & 5.4600 & 5.4600 & 5.4700 & 5.4600 & 5.4600 \\
\hline \multirow{7}{*}{ 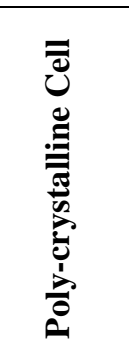 } & $\mathrm{n}_{1}$ & 1.3900 & 1.6700 & 1.7400 & 1.8200 & 1.6900 & 1.7700 \\
\hline & $\mathrm{n}_{2}$ & 0.7210 & 1.0500 & 1.0200 & 1.1500 & 0.9520 & 0.9920 \\
\hline & $\mathrm{R}_{\mathrm{S}}$ & 0.0349 & 0.2050 & 0.0965 & 0.1440 & 0.1320 & 0.0862 \\
\hline & $\mathrm{R}_{\mathrm{P}}$ & 50.5000 & 123.0000 & 74.4000 & 106.0000 & 64.6000 & 58.3000 \\
\hline & $\mathrm{I}_{\mathrm{O} 1}$ & $8.40 \mathrm{E}-08$ & $5.54 \mathrm{E}-07$ & $2.80 \mathrm{E}-07$ & $3.58 \mathrm{E}-07$ & $2.85 \mathrm{E}-07$ & $3.58 \mathrm{E}-07$ \\
\hline & $\mathrm{I}_{\mathrm{O} 2}$ & $6.26 \mathrm{E}-10$ & $1.26 \mathrm{E}-06$ & $1.51 \mathrm{E}-07$ & $1.43 \mathrm{E}-07$ & $1.38 \mathrm{E}-07$ & $3.80 \mathrm{E}-08$ \\
\hline & $\mathrm{I}_{\mathrm{PV}}$ & 8.2200 & 8.2200 & 8.2200 & 8.2200 & 8.2300 & 8.2200 \\
\hline \multirow{7}{*}{ 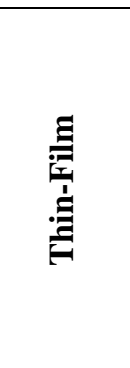 } & $\mathrm{n}_{1}$ & 1.6200 & 1.8200 & 1.8400 & 1.9200 & 1.8300 & 1.9000 \\
\hline & $\mathrm{n}_{2}$ & 1.5200 & 1.7600 & 1.7400 & 1.8000 & 1.8800 & 1.8200 \\
\hline & $\mathrm{R}_{\mathrm{S}}$ & 1.4700 & 1.2900 & 1.5600 & 1.4100 & 1.6400 & 1.7000 \\
\hline & $\mathrm{R}_{\mathrm{P}}$ & 0.0914 & 0.3150 & 0.1660 & 0.2540 & 0.1310 & 0.0997 \\
\hline & $\mathrm{I}_{\mathrm{O} 1}$ & 57.0000 & 130.0000 & 105.0000 & 107.0000 & 108.0000 & 117.0000 \\
\hline & $\mathrm{I}_{\mathrm{O} 2}$ & $8.59 \mathrm{E}-08$ & $5.42 \mathrm{E}-07$ & $3.11 \mathrm{E}-07$ & $4.35 \mathrm{E}-07$ & $3.84 \mathrm{E}-07$ & 4.47E-07 \\
\hline & $\mathrm{I}_{\mathrm{PV}}$ & $3.12 \mathrm{E}-06$ & 2.97E-06 & $1.25 \mathrm{E}-05$ & $2.86 \mathrm{E}-06$ & $1.56 \mathrm{E}-05$ & $1.72 \mathrm{E}-05$ \\
\hline
\end{tabular}

\section{REFERENCES}

[1] Chauhan, Anurag, and R. P. Saini. "A review on Integrated Renewable Energy System based power generation for stand-alone applications: Configurations, storage options, sizing methodologies and control." Renewable and Sustainable Energy Reviews 38 (2014): 99-120.

[2] Mohamed, Mohamed Abdelaziz, and Ali Mohamed Eltamaly. Modeling and Simulation of Smart Grid Integrated with Hybrid Renewable Energy Systems. Springer, 2018.

[3] Deshmukh, M. K., and S. S. Deshmukh. "Modeling of hybrid renewable energy systems." Renewable and sustainable energy reviews 12, no. 1 (2008): 235-249.

[4] Shannan, Nahla Mohamed Abd Alrahim, Nor Zaihar Yahaya, and Balbir Singh. "Single-diode model and twodiode model of PV modules: A comparison." In 2013 IEEE International Conference on Control System, Computing and Engineering, pp. 210-214. IEEE, 2013.

[5] Ishaque, Kashif, Zainal Salam, and Hamed Taheri. "Simple, fast and accurate two-diode model for photovoltaic modules." Solar energy materials and solar cells 95, no. 2 (2011): 586-594.

[6] Jordehi, A. Rezaee. "Parameter estimation of solar photovoltaic (PV) cells: A review." Renewable and Sustainable Energy Reviews 61 (2016): 354-371.

[7] Allam, Dalia, D. A. Yousri, and M. B. Eteiba. "Parameters extraction of the three diode model for the multi-crystalline solar cell/module using Moth-Flame Optimization Algorithm." Energy Conversion and Management 123 (2016): 535-548.

[8] Nishioka, Kensuke, Nobuhiro Sakitani, Yukiharu Uraoka, and Takashi Fuyuki. "Analysis of multicrystalline silicon solar cells by modified 3-diode equivalent circuit model taking leakage current through periphery into consideration." Solar Energy Materials and Solar Cells 91, no. 13 (2007): 1222-1227.

[9] Solar cell comparison: chart between mono, poly and thin films. National Renewable Energy Laboratory. Online : https://energyinformative.org/solar-cellcomparison-chart-mono-polycrystalline-thin-film/

[10] AlHajri, M. F., K. M. El-Naggar, M. R. AlRashidi, and A. K. Al-Othman. "Optimal extraction of solar cell parameters using pattern search." Renewable Energy 44 (2012): 238-245

[11] Ishaque, Kashif, Zainal Salam, Saad Mekhilef, and Amir Shamsudin. "Parameter extraction of solar photovoltaic modules using penalty-based differential evolution." Applied Energy 99 (2012): 297-308.

[12] Gong, Wenyin, and Zhihua Cai. "Parameter extraction of solar cell models using repaired adaptive differential evolution." Solar Energy 94 (2013): 209-220.

[13] Ma, Jieming, T. O. Ting, Ka Lok Man, Nan Zhang, Sheng-Uei Guan, and Prudence WH Wong. "Parameter estimation of photovoltaic models via cuckoo search." Journal of applied mathematics 2013 (2013).

[14] Rajasekar, N., Neeraja Krishna Kumar, and Rini Venugopalan. "Bacterial foraging algorithm based solar PV parameter estimation." Solar Energy 97 (2013): 255265.

[15] Appleyard, David. "Utility-scale thin-film: Three new plants in Germany total almost $50 \mathrm{MW}$." Renew. Energy World Mag(2009).

[16] AlRashidi, M. R., K. M. El-Naggar, and M. F. AlHajri. "Heuristic approach for estimating the solar cell parameters." Recent Researches in Applied Information Science (2012): 80-83.

[17] AlRashidi, M. R., K. M. El-Naggar, and M. F. AlHajri. 
"Solar cell parameters estimation using simulated annealing algorithm." World academy of science, engineering and technology 7, no. 4 (2013): 152-149.

[18] Mirjalili, Seyedali, Seyed Mohammad Mirjalili, and Andrew Lewis. "Grey wolf optimizer." Advances in engineering software 69 (2014): 46-61.

[19] Pradhan, Moumita, Provas Kumar Roy, and Tandra Pal. "Oppositional based grey wolf optimization algorithm for economic dispatch problem of power system." Ain Shams Engineering Journal (2017).

[20] Khandelwal, Ashish, Annapurna Bhargava, Ajay Sharma, and Harish Sharma. "Modified grey wolf optimization algorithm for transmission network expansion planning problem." Arabian Journal for Science and Engineering 43, no. 6 (2018): 2899-2908.

[21] Mittal, Nitin, Urvinder Singh, and Balwinder Singh Sohi. "Modified grey wolf optimizer for global engineering optimization." Applied Computational Intelligence and Soft Computing 2016 (2016): 8.

[22] Yang, Bo, Xiaoshun Zhang, Tao Yu, Hongchun Shu, and Zihao Fang. "Grouped grey wolf optimizer for maximum power point tracking of doubly-fed induction generator based wind turbine." Energy conversion and management 133 (2017): 427-443.

[23] Madhiarasan, M., and S. N. Deepa. "Long-term wind speed forecasting using spiking neural network optimized by improved modified grey wolf optimization algorithm." Int. J. Adv. Res 4 (2016): 356-368. 